\title{
Developmental Phases in Regulation Education: A Case Study of Care Worker Education in Japan
}

\author{
Meng Lanfang \\ Researcher in JAIST, Japan \\ Farida Ibrahim Ramadan \\ A doctoral student, JAIST Japan
}

\author{
Zuraidah Zaaba \\ UiTM Malaysia, Sabah Campus \\ Katsuhiro Umemoto \\ Graduate School of Knowledge Science, \\ JAIST Japan
}

\begin{abstract}
The rapid progress of aging in Japan, has caused care needs to become diversified and dynamic. Although care worker education has only existed for 40 years there are high expectations of care worker education to train high-level care workers. Furthermore, the curriculum of Certified Care Worker Education (CCWE) is still at an exploratory stage. This paper adopts a case study to analyze changes of care worker education. The findings show that first, educational ideals and educational purposes have changed from training workers with special knowledge and skills, to caring for human dignity and independence. Second, varieties of academic disciplines were changed and integrated into care academic discipline in educational contents. Third, teaching methods has shifted teaching for care knowledge and skills from the positions of care workers and care facilities to care receivers. Finally, we conclude that the development of regulation education has gone through three phases. They are individual development, integrated and continued development, and differentiation development.
\end{abstract}

\section{Introduction}

Japan is categorized as a "super-aged society" because in 1970, the aged population (people aged 65 years old and over) percentage was just over 7\%; and as of October $1^{\text {st }}$, in 2011, the aged population percentage has reached 23.3\%; and Japan family structure changed from extended families to nuclear families. Hence, care for the elderly by family members has become more difficult and this has resulted in a greater demand in social supports for care services.

The Japanese government is aware of the importance of social services for elderly people and has worked continuously to formulate welfare policies. These had put additional demands on care workers and much better care services for the elderly is desired. In order to provide high-quality services, care workers are required to have special knowledge and skills.
Studies showed care worker education began in the early 1970s with a few medical professionals and social welfare professionals who were aware of the need to train care worker professional. They trained care workers in a few pioneer educational institutions [1][2][3]. Certified Social Workers and Certified Care Workers (CCW) Act was formulated in 1987; and CCWE was offered in 25 higher educational institutions (junior colleges and professional schools) in 1988. These 25 institutions also included the pioneer educational institutions. This education was the foundation of care worker education before the Certified Care Workers Act in Japan [1]. In 2012, there are 383 educational institutions of CCW [4], and more than $60 \%$ are professional schools [5]. Unfortunately, these educational institutions of CCW are seriously under-enrolled. The reasons are as follows [6]:

- Low fertility rate of the population resulting in low members of 18 -year-olds

- Educational institutions of CCW increase rapidly

- It is increasing rapidly to pass the national examination to become $\mathrm{CCW}^{1}$

- Salary, position and duties offer to CCWs are similar to helpers and care workers with no qualification.

- Less training hours for a two-year course (professional school and junior college) lead to difficulty in fostering professionals with high levels.

Although the care worker education has only spanned for 40 years from the beginning of pioneer education, and only spanned for 20 years from the Certified Care Workers Act, the education is still at an early stage. Hence, there are many problems in CCWE. i.e. educational contents and teaching methods.

The academic disciplines of CCWE include a wide range of knowledge such as care and nursing, social welfare, home economics, medical and

\footnotetext{
${ }^{1}$ There are two alternative to earn the qualification of Certified Care Worker, the first alternative is to enroll in CCWE course, second is to sit for national examination for individuals who have five years working experience in care fields.
} 
psychology. Therefore, the teachers of CCWE are professionals with different backgrounds. Many researchers of CCWE are teachers at the educational institutions of CCW. We found that many studies are only focusing on one academic discipline of CCWE, i.e. studies on full-time teachers' major fields or the subjects taught. This discovery was after reviewing all issues discussed in the Japanese journal of "Care Worker Education (Kaigo Fukushi Kyoiku)" [7], In addition, many studies are on the present CCWE. But, there are few studies on the whole curriculum, and there is no comprehensive study from the inception of care worker education to present CCWE.

Generally, teachers of educational institutions think that the curriculum, educational contents and, teaching methods related to teachers' interactions with their students are important. Teaching methods of care worker education is still a tacit knowledge because there are few studies about teaching methods on several subjects or academic disciplines, and there is no study of teaching methods for the whole of care worker education.

\section{Objectives and methodology}

This study analyzes the inception of care worker education to the present CCWE, and aims to clarify the following research questions:

- How did the educational ideals or educational purposes of care worker education change?

- How did the educational contents of care worker education change?

- How were the teaching methods of care worker education being devised?

In order to clarify these research questions, we apply a case study strategy.

First, we analyze the care worker education in five pioneer educational institutions before the Certified Care Workers Act was formulated. The established order of the five educational institutions is as follows [1]:

- Osaka Mead Christian Community College (1972)

- Welfare Medical Helper School Attached to Seri Gakuen Hamamatsu Health Junior College (1978)

- Ube Junior College Home-care Course (1983)

- Osaka Community Worker Professional School Community Care Department (1984)

- Izumi Elderly Welfare Professional School (1985)

Second, we analyze the legislation and integration of CCWE developed by the Ministry of
Health, Labor and Welfare (MHLW). We also analyze social welfare policies and Acts, reports and notification of the CCWE from the MHLW.

Finally, we analyze each CCWE based on three categories of educational institutions specified by the MHLW. The three categories are professional school, junior college and a four-year university course. We analyze the following three institutions: (For ethical reasons, we refer the institutions as $\mathrm{A}, \mathrm{B}$ and $\mathrm{C}$ ):

- Care welfare department of A Welfare Professional School

- Welfare department of B Junior College

- Care support course of human welfare department, C University

We analyze educational ideals or educational purposes, curricula and teaching methods. In curricula analysis, we focus on changes of curricula in chronological order. We also compare the curriculum of each educational institution with the standard curriculum each time it was revised by the HMLW. Through the comparative study we are able to clarify the direction of changes in curricula and characters of different categories of educational institutions of CCW.

The primary data was collected through semistructured interviews with teachers from the three educational institutions of $\mathrm{CCW}$. The interviews were recorded with the consent from the interviewees. The secondary data was curricula, syllabi, course guidelines, commemorative magazines, self-evaluation reports and the websites of educational institutions.

\section{Case Studies}

\subsection{Care worker education in five pioneer educational institutions}

The common social situations of education in the pioneer educational institutions were as follows:

- Aging society progressed rapidly

- Elderly care workers had limited special knowledge and skills

- Elderly dissatisfied with the care services

The educational purposes of the pioneer educational institutions were varied, e.g. to train home aids; to assist people that required caring at home; to train helpers who acquire the knowledge and skills of nursing to assist the elderly at nursing homes; to train assistants of nurses; to train clinical welfare professionals and to train the elderly welfare professionals.

Based on the educational purposes, the educational contents and the importance of the 
contents were also difference in the pioneer educational institutions [1]. Up to 1983 the curricula focused on nursing knowledge, since 1984, the word "kaigo (care)" was first used in the curriculum of Osaka Community Worker Professional School. Following that, in 1985 Izumi Elderly Welfare Professional School started, and developed four main subjects used "kaigo". The change from "nursing" to "kaigo" is an important turning point for care worker education.

\subsection{The development of CCWE by the MHLW}

The regulation standards of Certified Social Workers and Certified Care Workers Arts include: "Regulations for educational institutions of Certified Care Workers", and more detail performance standards, "Teaching guidelines for educational institutions of Certified Care Workers". Based on the regulations and the guidelines, educational institutions of CCWs are specified by the MHLW.

The regulations are as follows:

- Entrance requirements

- Periods of study

- Educational contents

- Number of full-time teachers and the requirement for full-time teachers

- Requirement of teacher who organize the CCWE include curriculum development

- Teacher requirement of every academic discipline

- Classroom and seminar room

- Practice machines

- Practical training.

- Libraries of books in the field of Care Workers

The guidelines include:

- Established plan in educational institutions of $\mathrm{CCW}$

- School regulations including establish purposes, school name, station, periods of study, fixed number of students, subjects and methods of taking classes etc.

- Details relating to students, teachers, education, educational facilities and practical training

Earlier, there were unspecified educational ideals and educational purposes of CCWE. The initial standard curriculum was divided into liberal arts subjects and specialized subjects. The educational goal of each subject and content were clearly specified.

In order to acquire wide knowledge, the subjects of liberal arts were more than 120 credit hours from international science, social science, natural science, foreign language or health and physical education were required to be taken.

The specialized subjects were 1380 credit hours that included various academic disciplines such as social welfare, home economics, care, medical science, rehabilitation and recreation. Subjects related to care knowledge and skills are 810 credit hours. Care knowledge and skills were taught in educational institutions for only 360 credit hours, 450 credit hours are practical training outside of educational institutions. In practical training, the care workers of the fields teach students care skills.

In 1999, standard curriculum was revised for the first time, and "The Expectations of Certified Care Worker" as educational purposes were first presented. These are as follows:

- To foster a rich humanity and broad range of general knowledge, communicate successfully

- To create trusting relationships with care receivers

- To care in planned manners according to the situations of care receiver

- To respect human rights and life of care receivers

- To care from the perspective of independence support

- To cooperate with professionals of health, medical and welfare

- To do self-study

- To teach junior workers

The revision of "liberal arts subjects" had changed to "basic area", the contents of liberal arts had changed to basics of specialized knowledge "understanding human beings and the life", "human dignity"; specialized subjects increased 150 credit hours including 90 credit hours of care knowledge, 30 credit hours of social welfare policies and 30 credit hours of medical knowledge.

In 2007 standard curriculum was revised for the second time. "Required Images of Certified Care Workers" and "The Training Purposes of CCWE at the Time of Obtaining Qualification (資格取得時の 介護福祉士養成の目標)” were presented. These were regarded as educational ideals and educational purposes.

We summarize the "Required Images" as follows:

- Dignity care

- Practical ability

- Independence support

- Care ability at home-nursing and home

- Psychological supports and social supports

- Responding to changes of care receivers' situation 
(prevention $\rightarrow$ rehabilitation $\rightarrow$ care)

- Team care cooperating with different professionals

- Basic correspondence can be performed by oneself

- Practice individual care

- Communication skills, record and descriptive skills

- Understanding the related areas

- High level of ethics

"The Training Purposes of CCWE at the Time of Obtaining Qualification" were clearly-indicated as follows:

- Considering from other persons' standpoints

- Learning basic care knowledge and skills

- Understanding the evidence of care practice

- Understanding the significance of bringing out potential of care receivers, utilizing and exercising

- Understanding the necessity of team worker

- Understanding policies of social security

- Understanding the roles of other professions

- Acquiring ability to provide comprehensive and planed services

- Acquiring basic communication skills

- Acquiring the methods of recording and description skills

- Respecting human rights and professional ethics

In this revision specified subjects were replaced with specified domain by the MHLW. The new curriculum comprised of three domains:

- Human beings and society (240 credit hours)

- Care (1260 credit hours)

- Mind and body (150 credit hours)

In each domain, the educational contents and foster purposes were regulated.

The contents of domain "human beings and society" include:

- Human dignity

- Independence supports

- Interpersonal relationship and communication

- Policies of social welfare

These contents were developed with reference to "for care".

In the contents of "care" domain, care knowledge and skills were emphasized from the viewpoint of human dignity and independence supports. Training hours of care knowledge and skills were increased to 1260 credit hours. This was $70 \%$ of the total training hours.
The contents of "mind and body" domain were:

- Human growth, development and aging from the medical perspective

- Knowledge of dementia and disabilities

In 2011, standard curriculum was revised for the third time, this revision only replaced "mind and body" domain to "mind, body and medical care". The contents of medical care include:

- Basic knowledge of sputum suction and tubal feeding (50 credit hours lecture)

- In-house practical training

- Practical training in care fields

\subsection{CCWE in educational institutions specified by the MHLW}

In this section we choose three categories of educational institution of $\mathrm{CCW}$, they are professional school, junior college and a four-year university course. We analyze the changes of CCWE in educational institutions to conform to the regulations and guidelines of CCWE by the MHLW.

\subsubsection{Care welfare department of A Welfare Professional School}

In 1990, A Welfare Professional School initiated CCWE. The founder was a professional musician. He introduced "music therapy" in the curriculum of CCWE in Japan.

The educational ideals of A Welfare Professional School were:

- Value artistry

- Development of individuality

- Mutual trust

- Cultural accomplishment and manners

Educational ideals and educational purposes only for CCWE were not clearly defined in care welfare department. The changes of the educational contents as follows:

- Individual subjects were maintained such as "music", "music therapy", "special seminar" and "first aid and resuscitation tech"

- Educational contents of liberal arts were reduced; human dignity and independence supports were strengthened

- Contents of social welfare and home economics were reduced

- Contents of music, home economics, rehabilitation and recreation were integrated to care academic discipline

- Liberal arts and the surrounding of academic 
disciplines for care were reduced; care knowledge and skills were strengthened

Based on the interviews with the teachers of $\mathrm{A}$ Professional School, we summarize the teaching methods as follows:

- Teachers not only transferred knowledge and skills to students top-down, they made students to proactively participate in classes, and emphasized interactions of teachers and students

- Implemented group work in class, seminar and practical training and assigned group tasks

- Individualized instruction

- Expressed high expectations for students

These teaching methods can be an effective method to build interpersonal relationships between teachers and students, among students, motivate students, encourage active learning and cooperation among students, stimulate each other and improve students' communication skills.

\subsubsection{Welfare department of B Junior College}

Individual curriculum development of CCWE is difficult in Junior colleges. "Within two years, it is difficult to add more subjects and training hours over the standard curriculum and to request students to take more classes [8]". Welfare department of B Junior College attempted ten-year education. Ten years include:

- Three years for "introduction education before entering college" in high school

- Two years for "professional education while in B Junior College"

- Five years for "development education after graduation"

This was selected as "Good Practice (GP)" by the Ministry of Education, Culture, Sports, Science and Technology in 2003. [9]

Based on educational ideals of B Junior College, welfare department set up educational ideals for CCWE. The educational ideals were to build a normalization of society which all members of society could live together in the spirits of a rich humanity, independent and solidarity.

The educational purposes of welfare department changed based on the educational ideals, social development and social demands. The first educational purposes were:

- To foster independent-minded ordinary citizens

- To foster high level professionals responsible for welfare such as Certified Care Workers

- To expect improvement of social welfare and human life, development of welfare culture in community.

In 2008 the educational purposes has changed as follows:

- To foster CCWs and the related professionals with special knowledge and skills for supporting dignity and independence of care receivers

- To teach related welfare and care knowledge, such as knowledge of social welfare, life welfare and care welfare

The changes of the educational contents were as follows:

- Liberal arts were reduced, instead knowledge of human dignity and communication were strengthened

- Ten individual subjects related knowledge of social welfare and human life

- New curriculum "care welfare professional theory" and therapy skills for psychological care such as "horticulture therapy", "picture therapy"

- Knowledge of social welfare, rehabilitation and recreation were maintained in B Junior College that was omitted or reduced by the MHLW

Based on the interviews with the teachers of B Junior College, we summarize the teaching methods as follows:

- Gave students empirical examples of teachers and seniors

- Picked up themes which connect with real life

- Selected various teaching materials and new welfare information

- Gave instruction before and after practical training of the care fields

- Implemented group work in classes, seminars and practical training

- Created environment for students to communicate easily with teachers

- Appropriately praised students to encourage them

These teaching methods enable students to learn a wide range of knowledge and new knowledge, increase students' desire to learn, and built national internships between teachers and students and among students.

\subsubsection{Care supports course of $C$ University}

Universities that have stopped the recruitment of students increased from one to eight beginning in 2008 until 2012. In June 2012 there are 67 universities offering a four-year course of CCWE. [10]. 
In C University, educational ideals and educational purposes were set up clearly. In care support course only educational purposes were set up as follows [11]:

- To foster practical ability of making care plan to respond to individual care needs

- To clarify the ways of cooperation with health and medical professionals, such as "team approach" and "care management"

The changes of curriculum are as follows:

- Enhanced educational contents of liberal arts from the beginning

- Consistently only had few individual subjects

- Maintained most contents in the new curriculum that was omitted or reduced by the MHLW

- Strengthened the contents of normalization such as human dignity, independence supports based on the revisions of standard curriculum

Based on the interviews with teachers, we summarize the teaching methods as follows:

- Gave students many examples of teachers' experiences

- Showed DVDs and gave out printed materials to help students to understand

- Took much time to teach students on a one to one basis

- Had high expectation of students in order to become care leaders

\section{Findings}

\subsection{The changes of the educational ideals and educational purposes}

There were different varieties of educational purpose in the pioneer educational institutions. We discovered from these educational purposes that the training changed from care at home to care at nursing homes, from home care and nurse assistance to welfare support and care support for the elderly.

The educational ideals and educational purposes of CCWE were unspecified by the MHLW from the beginning. Later the "Expected Images of Certified Care Workers" were indicated [12]. Then "Educational purposes of CCWE at the Time of Get Qualification" and "Required Images of Certified Care workers" were presented [13]. The educational ideals and educational purposes changed from physical care to psychological and social support, and practice of care to support the care receivers' dignity.

In the educational institutions specified by the MHLW, educational ideals and educational purposes only for CCWE were not necessarily indicated. Educational ideals of educational institutions remain almost unchanged, though some educational institutions changed educational purposes based on the expectations of CCWs and changes of care needs.

\subsection{The changes of the educational contents}

In the pioneer educational institutions, there is a significant change for care workers education, when the subject names were replaced from "nursing" to "care".

In the case of standard curriculum specified by the MHLW, after the curricula were revised three times, the liberal arts courses were reduced, and social welfare ideals such as human rights, human dignity and independence support were strengthened. The specialized subjects focused on three domains. They were care, social welfare and home economics. After the curriculum revisions, care knowledge and skills were increasingly strengthened. Knowledge of social welfare and home economics were reduced and integrated to the academic discipline of care.

Changes of liberal arts in specified educational institutions were, in two-year courses at A Welfare Professional School and B Junior College, liberal arts were reduced, on the other hand basic of specialized knowledge were strengthened. And in four-year course at $\mathrm{C}$ University, from the beginning the contents of liberal arts were enhanced and maintained consistently. Changes of specialized academic disciplines in specified educational institutions were stated later.

Initially, in A Welfare Professional School, there was a development of eight individual subjects such as "music therapy". Later with the curriculum revisions the individual specialized subjects were gradually reduced. The new curriculum only retained two individual subjects.

In B Junior College, initially, there was a development of a number of subjects related to social welfare and human life. In a new curriculum, the contents that related to academic disciplines, such as social welfare, medical science, rehabilitation and recreation were reinstated. Individual subjects such as "Certified Care Workers professional", "horticultural therapy" and "picture therapy" and "career design seminar" were developed.

In $\mathrm{C}$ University, in order to obtain both qualifications of $\mathrm{CCW}$ and Certified Social Worker (CSW), students enrolled in all subjects of both qualifications specified by the MHLW. Therefore, there were few original contents in a four-year university courses. The contents related to "understanding dementia" and "care processes" were added in order to conform to the standard curriculum revisions. The contents related to social welfare, home economics, medical science, rehabilitation and recreation which were reduced or omitted by the 
MHLW were maintained. Few original contents included basic knowledge related to research and care management, palliative care, terminal care and no lifting care skills.

\subsection{The devised teaching methods}

In this paper, we analyze the teaching methods by curriculum and learning-support. Based on teaching methods, curriculum is divided into three types; they are lecture, seminar and practical training. During lectures the method of having seminars was sometimes conducted. In order to easily understand and facilitate the images of elderly care for students, during lectures and seminar classes, teachers gave some success or failure care examples that teachers and senior students had experienced. They showed videos and distributed handouts to students. In the course of practical training, educational contents included practice in welfare facilities and home visits for care, teachers gave guidance before and after the practical training, went to practical training gave students guidance once a week. In practice guidance, teachers focused on individual teaching.

Learning-support for students included:

1. Supporting students to communicate comfortably with teachers and building trust through communication.

2. Avoiding top-down knowledge transfer from teachers to students, focusing on interaction between teachers and students, promoted active participation in class.

3. Understanding and detecting students' understanding through, for instance, tests, reports, finally giving feedback to students.

4. Conveying high expectations and encouraging students for care work.

These teaching methods were maintained. The change was only for teaching care knowledge and skills from the standpoint of care welfare facilities and care workers to the position of care receivers.

\section{A theoretical model of regulation education development}

In each pioneer educational institutions, educational purposes were clarified. Original curriculum was developed according to the educational purposes. Care worker education was conducted. Care worker education was formed and developed in individual educational institutions.

The MHLW developed standard curriculum by referring to the curricula of pioneer educational institutions. The MHLW institutionalized and legislated care worker education that promoted the spread of care worker education. Care worker education was integrated by the MHLW.

Each educational institution specified by the MHLW is conducting CCWE. But each educational institution of $\mathrm{CCW}$ has individually developed to conform to the regulations, thereby care worker education was differentiated.

Standard curriculum specified by the MHLW was revised three times. Teachers from educational institutions of CCW took part in these curriculum revisions. When educational institutions of $\mathrm{CCW}$ plan to change some contents of their education system, such as curriculum and teachers, they have to submit a report about the changes to the HMLW. This means educational institutions of CCW have continuously giving feedback to the HMLW. Educational institutions of CCW and the HMLW are continuously interacting with each other.

Based on the findings obtained from the analysis of formation and development of care worker education, we developed "A theoretical model of regulation education development". See Figure 1, this model consists of three phases; they are "individual development education", "integrated and continuous development education" and "differential development education".

\begin{tabular}{|c|c|c|}
\hline $\begin{array}{l}\text { Phase of } \\
\text { individual } \\
\text { development } \\
\text { education }\end{array}$ & $\begin{array}{l}\text { Phase of integrated } \\
\text { and continuous } \\
\text { development } \\
\text { education }\end{array}$ & $\begin{array}{c}\text { Phase of } \\
\text { differential } \\
\text { development } \\
\text { education }\end{array}$ \\
\hline
\end{tabular}

Figure1. A theoretical model of regulation education development

\subsection{Phase of individual development education}

Based on social needs and policies, few experts become aware of the necessity of an education. They set up educational purposes, develop curricula and conduct practice teaching. This education is formed in pioneer educational institutions. In addition practical teaching curricula are revised and developed. The education is formed and developed in individual pioneer educational institutions.

\subsection{Phase of integrated and continuous development education}

Finally, the government recognizes the needs of training the professionals to cater for the social needs to legislatean education. And the government takes advantage of the experience knowledge accumulated by pioneer educational institutions, to set educational ideals and purposes and to develop standard curriculum. Standard curriculum is developed through maintenance, addition, strength and omission. This development is with reference to curricula of a few pioneer educational institutions. 
This means that regulation education is developed by changing and integrating the previous education. In order to respond to social needs, the regulation education is revised repeatedly for this education to continuously develop.

\subsection{Phase of differential development education}

In each specified educational institution, a unique education is developed according to the regulations and outlines such as educational ideals or educational purposes and curriculum. These are differential development processes for integrated development by government. Specified educational institutions continue to give feedback through reports of education revisions, teachers and practical research to regulation education specified by government.

\section{Discussion}

Educational ideals and educational purposes are the bases of education and offer directions for education development. They are very important in education. Initially educational ideals and educational purposes of CCWE were not clearly presented by the MHLW. These were later indicated in the curriculum revisions. These ideals and purposes were only based on the contents of textbooks [14] i.e. only accumulated care welfare practice and education history up to now [15]. This means until now the expertise of $\mathrm{CCW}$ was not clarified clearly. The MHLW should create more high level educational ideals and purposes. In order to create an individual focused education system, every specified educational institution of $\mathrm{CCW}$ should be set up clearly with regards to educational ideals and purposes.

Liberal arts education was reduced by the HMLW. Most of the contents of liberal arts were reduced in two year courses of CCWE. In CCWE the elective subjects of "human beings and society" include liberal arts education, and skills education is also emphasized [16]. Social welfare is the interdisciplinary science and basis of social sciences. Care welfare services as a social service demand the workers to have a rich knowledge that include ethical values. The liberal arts should be strengthened in professional school and junior college. In fact, in two-year courses of CCWE there is no time to add new contents to comply with the standard curriculum. It is necessary to develop education course of $\mathrm{CCW}$ over two years to strengthen the liberal arts education.

The standard curriculum was revised. Knowledge related to care domain was reduced and integrated into care domain. In curriculum revisions care knowledge and skills were added gradually; contents of care became broad and in-depth. In Japan "CCW is categorized as profession of social welfare. [1]. However, as the contents of social welfare were reduced greatly in the new curriculum; According to the changes of the curriculum, the $\mathrm{CCW}$ can be only categorized as the profession of "care worker" (CW).

In a four-year university course, in order to foster high level professional and leader of care workers, the requirement to make students obtain both qualifications of CCW and CSW should be halted. It should develop more in-depth care knowledge and skills to improve professional standards of work, in order to differ with CCWE in professional school and junior college. In response to these, the government should set up curriculum only for a fouryear university course, and to make a new policy to reposition the graduates of a four-year university course.

\section{Conclusion}

Regulation education are various according to these three phases i.e. elementary education, secondary education and higher education (to train health care professionals, doctors and medical nurses). However, the phase of individual development only occurred once. The phase of integrated and continuous development and the phase of differential development are repeated in the form of a spiral. Through the interactions of two phases; phase of integrated and continuous, phase of differential development, regulation educations will constantly develop.

We objectively analyzed the changes of curriculum. In the future it is necessary to verify the validity of the curriculum. Therefore, it is necessary to create a curriculum evaluation system, particularly a curriculum evaluation standard.

As mentioned earlier the educational institutions of CCW were under-enrolled and some educational institutions have stopped recruiting students. Furthermore, even the graduates of the educational institutions of $\mathrm{CCW}$ have to pass the national examination to obtain the qualification from 2015. To respond to these situations it can be expected that each educational institution of CCW will develop an individual education system to raise the national examination pass rate and strengthen competitiveness. Hence, in the future there is significant value to study CCWE from the perspective of service.

Our future research will verify the creation and revision processes of the standard curriculum through interviews of the persons involved.

\section{References}

[1] Meng, L.F., Zaaba, Z. \& Umemoto, K, "Formation and Development of Certified Care Worker Education in Japan: Perspectives of Knowledge Creation and Evolution", 
International Journal for Cross-Disciplinary Subjects in Education (IJCDSE), Volume 3, Issue 1, 2012, pp.669-676.

[2] T. Okamoto, "The Formation and Direction of Care Education", book chapter in T. Okamoto, et al Introduction of Care Welfare, Chuohoki, Tokyo, 2000, pp.149-160. (岡 本千秋（2000）「介護福祉教育の形成と方向性」岡 本千秋ほか編著『介護福祉学入門』中央法規).

[3] S. Osawa, "The Promotion of Education for Social Service Professionals in Japan: A Case Study on HELPER GAKUEN, A Non-profit Education Organization for Service Workers", Research Journal of Care and Welfare, Vol.10, Tyuohoki, Tokyo, 2003, pp.88-94. (大澤史伸 (2003)「N P Oによるヘルパー教育が介護福祉教 育に与えた影響—『へルパー学園』の事例研究一」 『介護福祉学』）。

[4] The website of "the Japan Association of Training Institutions for Certified Care Workers". (2 Dec. 2012). 社団法人 ・ 日本介護福祉士養成施設協会.

[5] Meng, L.F, The Changes of Educational Knowledge System Regulated: Case Study of Care Welfare Education. Library of the Japan Advanced Institute of Science and Technology(JAIST), Ishikawa, 2012.(doctoral paper) 孟 蘭芳（2012）、博士論文「規制を受ける教育知識体 系の変遷一介護福祉教育の事例研究一」博士論文、 北陸先端科学技術大学院大学.

[6] Website of Certified Care Worker Index, www.kaigofukusisi-index.jp/whats/present.html (16, Nov. 2011), 介護福祉士インデックスのウェブサイト.

[7] Japan Care Education Society, Journal of Care Worker Education (Kaigo Fukushi Kyoiku) No.1 No.28.

[8] N. Sawa, "About the Outline of Curriculum for Certified Care Worker Education in Junshin Women Junior College", Junshin Social Welfare Education Resaerch, No.25, 1995, pp.64-68. (澤宣夫（1995）「純 心女子短期大学介護福祉士養成カリキュラムの概要 について」『純心社会福祉教育研究』).

[9] S. Miyata, "Care Worker Education and 'GP' (Good Practice): The Comprehensive Formation of Professionalism and Humanity [in Japan]" Journal of Toyama College, 43(1), 2008, pp.87-96. (宮田伸朗（2008）

「福祉人材養成教育と『G P』一専門性と人間性の 統合的形成一」『富山短期大学紀要』).

[10] Website of Certified Care Worker Training University Liaison Council. http://www.kaigouniversity.com/wp/?p=64. (2, Nov. 2012), 介護福祉士養 成大学連絡協議会のウェブサイト.

[11] Course Guide of C University 2001.

[12] Notification of the Certified Social Workers and Certified Care Workers Act, "Regulations for Specified Training Facility of Certified Social Workers and Certified Care Workers Vocational Skills Development Schools".
[13] Notification of the Certified Social Workers and Certified Care Workers Act, "About Teaching Guidelines of Training Facilities for Certified Care Workers".

[14] Y. Nishimura, "The Direction of Education Based on the Expertness of Care Welfare", book chapter in Y. Nishimura \& T. Ota, Vision of Care Welfare Education, Kouseikan, Tokyo, 2008, pp.98-115. (西村洋子（2008） 「介護福祉の専門性に基づく教育の方向性」西村洋 子・太田貞司『介護福祉教育の展望一カリキュラム 改正に臨夕』光生館)).

[15] N. Sawa, Discussion Meeting, "The Direction of Certified Care Worker Education in the New Curriculum", Journal of Care Worker Education, No.25, 2008, pp.64-68. (澤宣夫(2008)「座談会・新カリキュラムにおける介 護福祉士養成教育の方向性」『介護福祉教育』).

[16] K. Shimizu, "Significance of Liberal Arts Education in Social Welfare Professional Education", in Proceeding of the $58^{\text {th }}$ Japanese Society for the study of Social Welfare.2010. (志水幸 (2010)「社会福祉専門職養成教 育における教養教育の意義一福祉系 4 年制大学にお ける教育課程を中心に一」『日本社会福祉学会 第 58 回秋季大会』 